страны, участвуя в процессах глобализации и производя уникальную, востребованную продукцию.

$$
* * *
$$

1. Кастельс М. Информационная эпоха: экономика, общество и культура / Пер. с англ.; под науч. ред. О.И. Шкартана. М. ГУ ВШЭ. 2000. С. 348.

2. О'Коннор, Дж. Культурное разнообразие, развитие и глобализация // Новые форматы партнерства. Серия: Культурные стратегии: Экспертный клуб. М. Институт культурной политики. 2004. С.28.

3. Петров И.Ф. Взаимосвязь и взаимообусловленность потребностей личности // Вестник ИМСИТ. 2014. № 1-2 (57-58). С. 11-20.

4. Петров И.Ф. Теории жизнедеятельности человека (на примере зарубежной философии) // В сборнике: ПЕРСПЕКТИВЫ МОДЕРНИЗАЦИИ СОВРЕМЕННОЙ НАУКИ Сборник статей Международной научно-практической конференции. Ответственный редактор: Сукиасян Асатур Альбертович,. 2015. С. 46-47.

5. $\quad$ Bock Ph. K. (Ed.). Culture Shock. A Reader in Modern Cultural Anthropology. N.Y., 1970.

\title{
Afanasieva T.Yu. Postmodern role in modern art
}

Belgorod state Institute of arts and culture (Russia, Belgorod)

doi: $10.18411 / l j-08-2020-107$

idsp: ljournal-08-2020-107

\section{Abstract}

This article is devoted to postmodern positions in contemporary art. The article considers art styles in the postmodern era, its role in the formation of marginal and conceptual art.

Key words: postmodern, art, value, culture, artistic style, simulacrum, paradigm.

Modern society is in a fundamentally new situation, which at the moment is not justified from the point of view of philosophy. like science. The most common explanation for this is the hypothesis of socio-cultural transformations of modern society and the idea of postmodernism. On the one hand, this attitude to postmodernism is due to the lack of correspondences in the past, which produces uncertainty of socio-cultural assumptions. On the other hand, the term "Modernity" raises many controversial questions of humanitarianism. Hence, a lot of questions arise. characteristics including socio-cultural space, socio-cultural direction in the development of culture, causality in the mechanisms of formation of sociocultural space, given the chance. A chaotic or deterministic degree of fundamental transformation of culture from modernism to postmodernism with the interpretation of the factors that predetermined the development of this process. A sequence occurs

Hence, the relevance of this article is also caused by the ingrained approach to modern and postmodern homogeneous, dynamic, despite their obvious complementarity with the signs of dynamically developing contradictory systems of views and values, forming on the one hand diametrically opposite vectors of individuality and their undoubted component in the fundamentalization of culture, on the other.Все это представляет собой сложную задачу, несмотря на явную очевидность в наступлении постмодерна, его развитие не закончилось.

The question of postmodernism in philosophy remains in the center of attention of researchers due to its undisclosed nature. The abundance of postmodern elements in research and scientific sources in culture and society as a whole to a greater extent reflect the interpretation of certain aspects of postmodernism to a greater extent in the translated literature. Moreover, the analysis of postmodern philosophy in domestic sources is subjective. Despite this, the outlines of postmodernism, as an epochal phenomenon, can be traced with certainty. This is how postmodern trends are reflected in Association with the post-industrial 
concept of society. There were also features of socio-economic aspects of postmodernism with the formation of postmodernism with the formation of ideas about postmodernism as a manifestation of the socio-cultural crisis.

The origins of postmodernism are enclosed in the origins of romanticism with figuraccia in this phenomena of marginality, of alogism, conflict of the creative personality and the existing everyday life of the phenomenon of specificity, can be transformed into recurrence with the antagonistic principle of the historical process. However, all of the analyzed literature sources, devoted to postmodernism, characterized by a lack of interconnectedness. Hence, it is very relevant to search for ways to connect fragments of the analyzed phenomenon in order to create a structural platform of postmodern philosophical discourse that can effectively implement their intended functioning. In the dynamics of the development of postmodern art, a certain stage can be traced: The first stage (a kind of "debut" of postmodernism in the 60s of the XX century) is characterized by resistance to modernist stereotypes with overcoming the differences between elite and mass art with the carnivalization of life; the emergence of various forms of art.

In 60-70gg. in France and later in Russia, the direction of graffiti was developed in pop culture, reflecting urban culture in the form of wall images. The second stage of postmodern art includes eclecticism and pluralism. A well-known researcher of postmodern art, U. Eco in her works demonstrated the features of this stage, based on the installation in literature of a regular approach to the formation of ready-made art forms based on the extraction of individual elements of texts and paintings by authors of the XVII century.

The third stage in the development of postmodern art since the late $70 \mathrm{~s}$ implies postmodern classicism, which has found its place in Russia in the form of monumentality and static.

As a postmodern characteristic with diverse currents, conceptual art includes metaphors and simulacra. An important role is assigned to rhizomatics, which is considered from the position of semantic multiplicity with elements of unpredictability and explosiveness.

Postmodern, as the dominant cultural vector, is characterized today as a term that combines artistic trends with a reinterpretation of the positions of modernity and reflects the modern status of society. Hence, the relevance of postmodern research becomes obvious.

However, it should be noted that a relatively small number of researchers from both Russia and abroad are currently engaged in postmodern issues.

In foreign literature, a detailed study can be traced only to three scientists (Jean Francois Liotard, Scott lash, Jurgen Habermas).

The literature of Russia, devoted to the research of philosophical problems and contain only the study developed signs of post-modernism.

Artistic style was an integral suburb of postmodernism, which was of great importance in the 50 s of the last century.

Writers of that era opened the meaning of art to a wide range of people with their extraordinary style.

In these conditions, a dominant postmodernism is created - the interpenetration with a clearly ironic revision of the past into the present, a high potential into a low level of art and the growth of a variety of aesthetic tastes.

The academic tone of modernism with the signs of a frozen curve gave rise to an optimistic impulse in the development of the future postmodernism, based, of course, on new computer technologies in the synthesis of arts.

The natural dynamics of postmodern art, covering the European space of the $70 \mathrm{~s}$, outlined the emergence of new phenomena of the next phase of postmodernism-pluralism and eclecticism. 
The concept of an ironic assessment of various aspects, including art, given in the works of the theorist U. Eco determined the surge of neo-art in literature (G. Marquez, H. Kortasar, H. Berkes, etc.), theater (S. Beckett, A. Artaud), cinema (R-V Fasbinder).

At the same time, new technologies endowed with early optimism are being used more to rethink and integrate the past.

A versatile ironic approach to assessing the previous principles formed the basis of the artists ' creativity, aimed at illustrating eternal themes and subjects from the position of their abnormality in the modern world.

In other words, aesthetic preference is an expression of the observer's taste, not a condemnation of the object, and D. Hume believes that the wide variety of opinions about art available in the world is a clear confirmation of this.

At first glance, the theory of D. Hume seems to correspond to reality. Artistic tastes differ greatly, but, in a broad sense, most people like and admire the same great masterpieces in music, painting, literature, or architecture.

However, contrary to D. Hume's suggestion, there is a General trend of most people's opinions that reveals a common taste, it does not establish a standard of taste. The fact that many people share feelings is not

The value of art is that it offers us entertainment. It should be noted that it is not always accepted to talk about art as a source of pleasure. People quite simply refer to novels, plays, and music as such sources, less often naming painting, sculpture, and architecture. There are several other points that need to be taken into account: Not all works of art are valued in the same degree.

Hence it can be concluded that the very existence of man and there is value, however, from the perspective of postmodernism, the value of a person is directed towards the imaginary areola existence, this determines the place of postmodernism in an improper charge to the individual cultural requirements and to develop his individuality.

In painting, the dynamics of postmodernism were reflected in a much greater acceleration of its development, compared to architecture. Already in the early 80's of the last century, a number of European exhibitions (London, 1980, Berlin, 1981, Paris, 1981, Rome, 1982) clearly marked the exhaustion of modernism and avant-gardism with the dominance of the born "transavangardism".

According to A. B. Oliva, "the Central ideas of art were structuralism and its linguistic component, with a vector for language determination".[5. P. 26] This theory is based on the emergence of completely new terms and symbols, the appearance of new contexts, which, according to A. B. Oliva, "determines evolution with variability and progress that fits into the logic of the development of the avant-garde." The transformation of art in the 70-80's becomes the basis of neo-avant-garde with useless currents that lead to despair, which led to the emergence of TRANS-avant-garde

The TRANS-avant-garde artist used elements of quotation, repetition, and other techniques to maintain, first of all, the level of local personality, with the exception of the universal significance of his work.

Postmodernism in art is characterized by an accentuation of the embodiment of pleasure, a mixture of high and low, elite and mass culture, as well as an indefinite position of the subject of artistic creativity.

However, most of them recognize the autonomy of the postmodern aesthetic system with obvious novelty, in comparison with modernity, in popular culture and the arts.

Postmodernism took its role in the art of the pictorial avant-garde, and in Russia, the underground, which determined its significance in the deconstruction of the past with the accentuation of pluralism in the thinking of the present.

Hence the emergence of new techniques, such as" neutral writing"," open work", which open up a broad perspective of the recipient's speculation in order to independently complete the reader or viewer's perception of the text. 
The end of the XX century is characterized by uncertainty of the past, present and future. In these conditions, the culture was left in limbo with a sense of its worthlessness and inevitable death.

As a complex phenomenon, postmodernism, as defined by J. F. Lyotard, is an "uncontrolled increase in complexity".

Postmodernism according to Z. Bauman- " this is modernism that has admitted its defeat and its impossibility, which requires significant adjustments»

$$
* * *
$$

1. Bauman, Z. Philosophy and postmodern sociology. Postmodernism and culture. [Text] / Z. Bauman // Question of philosophy. - 1993. - №3. - P. 46-61.

2. Genis, A. the tower of Babel: Art of the present time [Text] / A. Genis // Foreign literature. - 1996. - № 9. - 253S.

3. Graham Gordon Philosophy of art [Text]: introduction to aesthetics / Gordon Graham; [translated from English by M. O. Vasiliev]. - Moscow: Slovo, 2004. - 251, [1] p.: ill.; 21 cm. - (Big library "Slovo"). Bibliogr.: pp. 247-249. - Edict. - TRANS. view. : Philosophy of arts / Gordon Graham. - 1997. - ISBN 585050-733-7

\section{Afanasieva T.Yu. \\ Language competence as one of the aspects of forming students ' readiness for intercultural communication}

Belgorod state Institute of arts and culture

(Russia, Belgorod)

doi: $10.18411 / l j-08-2020-108$

idsp: ljournal-08-2020-108

\section{Abstract}

The Educational potential of the discipline "foreign language" in the formation of readiness for intercultural communication it is Known that the system of teaching a foreign language is determined primarily by social and economic factors. Political, socio-economic and cultural changes in Russia in the 90s significantly expanded the functions of a foreign language as a subject.

The modern system of teaching a foreign language is characterized by the fact that, first, practical knowledge of a foreign language has become an urgent need for broad segments of society and, second, General social contact creates favorable conditions for differentiation of foreign language teaching. The new socio-economic political situation requires the implementation of a policy in the field of foreign language education in society, aimed at meeting both public and personal needs in relation to foreign languages. The specificity of the subject of a foreign language is the orientation of the educational process to the personality of the student, the determinant of which in a certain sense is the language personality. As we have already noted, the concept of a secondary language personality - as a total verbal and semantic entity-is specific to a foreign language as an academic subject. To achieve the final result, it is necessary to master not only the appropriate foreign-language "technique", but also to learn a huge amount of extra-linguistic information necessary for adequate communication and mutual understanding at the intercultural level, as well as the development of such qualities that allow a person to communicate with representatives of other cultures. Therefore, the acquisition of a foreign language should be intertwined with the General ability to communicate in this language, its (communication) affective and cognitive aspects. It is, first, about the organization of communication at the intercultural level (in a broad cultural aspect) and, secondly, about the development of the student's needs and ability to participate in it. The result of this should be formed in the student's secondary language personality traits of a certain level, allowing him to participate in cross-cultural 